\title{
Değerli Hocam Prof. Dr. S. Yıldız Ötüken'in Anısına
}

\author{
Sema Doğan ${ }^{1}$ (D)
}

Türkiye'de Bizans sanatı araştırmalarına öncülük eden ve gelişmesinde büyük çaba harcayan, Hacettepe Üniversitesi Edebiyat Fakültesi Sanat Tarihi Bölümü Emekli Öğretim Üyesi ve Demre Aziz Nikolaos Kilisesi Kazılarının Onursal Başkanı Prof. Dr. S. Yıldız Ötüken’i 10 Eylül 2020 tarihinde kaybettik.

10 Aralık 1945 tarihinde doğan S. Yıldız Ötüken, babası merhum Adnan Ötüken'in görevi nedeniyle ilk ve orta öğrenimini Almanya'da almış, lise öğrenimini Ankara Kız Lisesi'nde tamamlamıştır. Üniversite öğrenimini Almanya'da sürdüren S. Yıldız Ötüken Ren Friedrich Wilhelm Üniversitesi'nde Alman Dili ve Edebiyatı Bölümü’nde lisans ve yüksek lisans eğitiminin ardından, doktorasını Bizans Sanatı üzerine Prof. Dr. Horst Hallensleben’in danışmanlığında “İsa Kapı Mescidi und Medresesi in İstanbul / İstanbul'da İsa Kapı Mescidi ve Medresesi” başlıklı doktora tezi ile tamamlamıştır. Daha sonra Türkiye’ye dönen Yıldız Ötüken 1975 yılında Hacettepe Üniversitesi Sanat Tarihi Bölümü’nde öğretim üyeliğine başlamış, 2011 yılında emekli oluncaya dek aynı bölümde akademik yaşamını sürdürmüştür.

Türkiye'de Prof. Dr. Semavi Eyice ile başlayan Bizans sanatı araştırmaları 1970'li yıllardan itibaren S. Yıldız Ötüken'in akademik ve bilimsel çalışmalarıyla ivme kazanmıştır. S. Yıldız Ötüken Bizans sanatının mimari, mimari plastik ve resim sanatı alanında Türk bilim insanlarının öncülerindendir. S. Yıldız Ötüken'in akademik yaşamı, Bizans sanatına değerli katkılar sunan pek çok ulusal ve uluslararası yayınlarının yanı sıra bu alanda yetiştirdiği öğrencilerle de farklılık gösterir. Lisans, yüksek lisans ve doktora düzeyinde yetiştirdiği öğrencilerinin önemli bir kısmı ülkemizde pek çok farklı üniversitede Bizans Sanatı üzerine araştırma yapan, dersler veren ve yeni kuşakları bu alanda yetiştirme çabası içinde olan akademisyenlerdir.

Prof. Dr. S. Yıldız Ötüken eğitim faaliyetlerinin dışında, farklı dillerde yayınladığı ulusal ve uluslararası makale ve kitaplar, yürüttüğü projeler, kazı ve yüzey araştırmalarıyla zenginleşen akademik çalışmalarını bilim dünyasına sunmuş, meslektaşları ve öğrencileriyle paylaşmıştır. Bizans sanatı araştırmalarına yadsınamaz katkısı olan Prof. Dr. S. Yıldız Ötüken gerek ülkemizde, gerekse yurt dışında saygın ve haklı bir yer edinmiştir.

1989-2009 yılları arasında Demre - Aziz Nikolaos Kilisesi Kazıları onun başkanlığında yürütülmüş, anıt yapının korunmasında ortaya koyduğu büyük emeğin yanı sıra kazı 
çalışmalarıyla bilim dünyasına yeni bilgiler sunulmuştur. Kazı çalışmalarında yetiştirdiği çok sayıda master ve doktora öğrencileri için Aziz Nikolaos Kilisesi bir okul, bir eğitim yeri olmuştur. Emekliliğine kadar devam eden Kazı Başkanlığını daha sonra ekip üyeleri olarak bizler devraldığımızda hocamızın Onursal Başkan olarak manevi desteğini daima yanımızda hissediyoruz.

Hacettepe Üniversitesi’nde lisans öğrenciliğim sırasında 2. Sınıfta tanıdığım ve o yıl Bizans Mimarisi dersine devam ederken Bizans sanatı alanında onunla birlikte çalışmaya karar verdiğim sevgili hocam Yıldız Ötüken, Sanat Tarihi Bölümü'nün doktoralı genç hocaları arasında en disiplinli, en sert ama aynı zamanda öğrencisine en yakın olandı. Alman disipliniyle akademik sistematiği bizlere aşılayan, özel bir öğretme yeteneğiyle Bizans sanatını sevdiren hocam, benim için uzun yıllar boyunca hocalığının dışında mesleki - etik ahlakı öğrendiğim kişi olmuştur.

Öğrenciliğimde ve sonrasında mesleki yolculuğumda bana kazandırdığı bilimsel disiplin, sabır ve mütevazılık, örnek aldığım hocamdan kalan mirastır. Onun çok değer verdiği ve 20 yıl boyunca yaşamının merkezinde yer alan Aziz Nikolaos Kilisesi Kazıları halen onun adıyla anılmakta, hatırasıyla devam etmektedir. Sevgili Hocam Yıldız Ötüken'i bir kez daha bu satırlarda özlemle, sevgiyle ve saygıyla anıorum.

Tüm bilim camiasının ve sevenlerinin bir kez daha başı sağ olsun. 

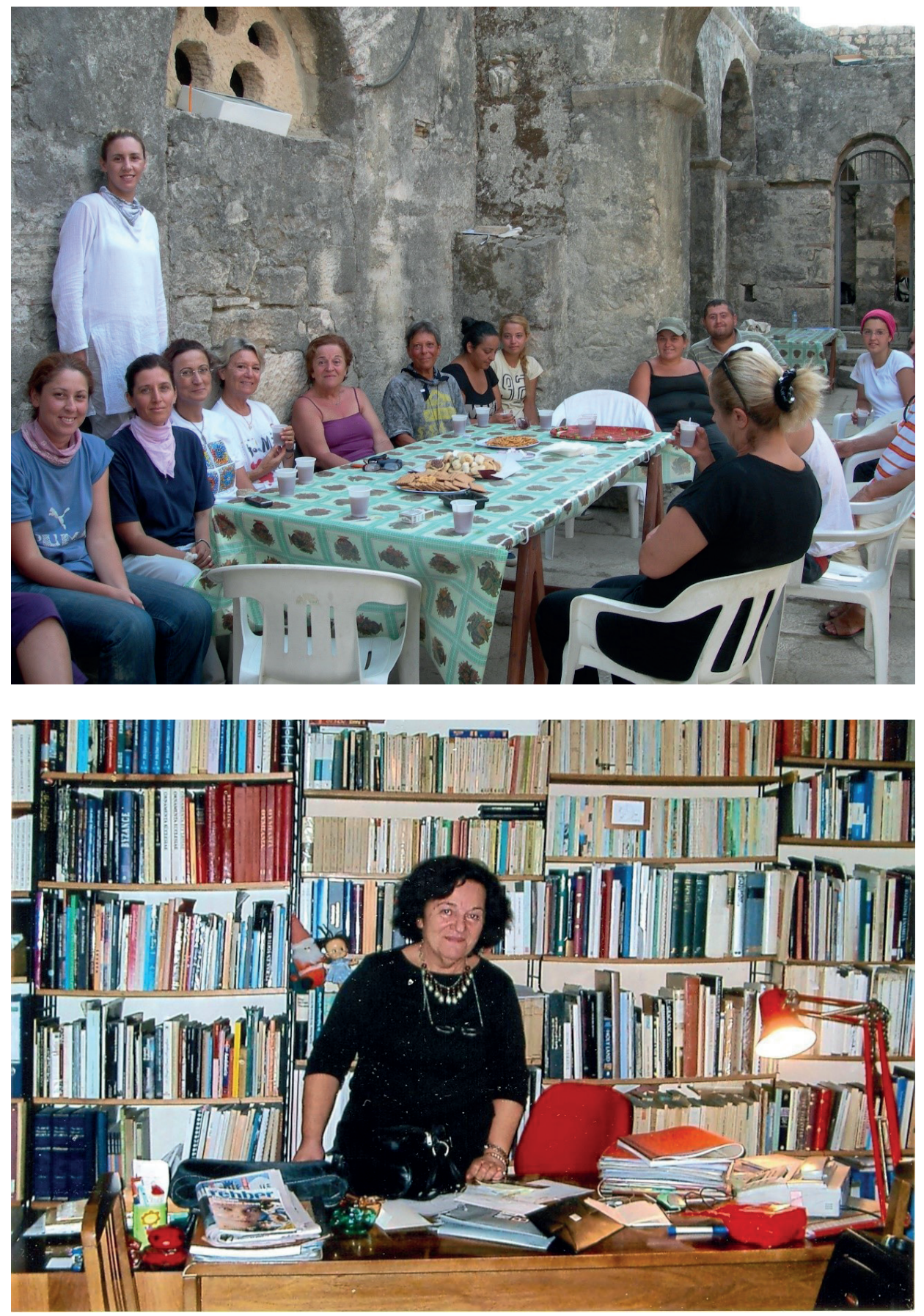
